\title{
MOTIF PENGGUNA MEDIA SOSIAL DALAM MENGUNGGAH INSTAGRAM STORY (Studi Fenomenologi Pada Anggota Sanggar Arastra di Kota Bengkulu)
}

\author{
Oleh: \\ YURINDAH, SRI NARTI, INDRIA \\ Program Studi Ilmu Komunikasi Fakultas Ilmu-Ilmu Sosial \\ Universitas Dehasen Bengkulu
}

\begin{abstract}
Instagram social media is a unique medium because through this media not only communicating by sharing photos, but also penetrating into videos that everyone can get various videos that inform various kinds of actifities or routines that are carried out. The use of instagram also occurs among the community in the city of Bengkulu, precisely Sanggar Arastra community, thus encouraging members to play Instagram. The purpose of this study is to find out the motives of social media users to upload instagram story. This study uses a qualitative research method with a qualitative descriptive approach and this study uses the motive theory by Papacharissi and Rubin (2017), which consist of several motives, utility motives and motives seeking information. This research was conducted with data collection techniques through interview, observation and documentation study. The subjects in this study were five members of Sanggar Arastra owning an Android or iOS cellphone with an application and an Instagram account, they actively play Instagram and like ti upload photos, videoa and texts on the Instagram Story. The results of thie study indicate that the motives of members of Sanggar Arastra in uploading photos, videos nd texts in Instagram story are convenience motives, entertainment motives, passing time motives to follow current trends. Of all the motives, there is the most dominant motive, namely Convenience Motives because what they upload on Instagram stories is a form of expressing themselves, a place to express feelings in the form of photos, videoa and texts. Their uploads form a good image in order to get the desired recognition.
\end{abstract}

Keywords: Motives, Instagram Story, Sanggar Arastra

\section{PENDAHULUAN}

Media sosial yang kini beragam merupakan jenis media baru yang memungkinkan orang bisa berbicara, berpartisipasi, berbagi dan menciptakan jejaring sosial online, Ardianto (2011). Media sosial yang saat ini sedang sangat diminati adalah instagram. Instagram berhasil meraih kepopulerannya tak lain karena kebiasaan masyarakat sekarang yang cenderung narsis. Instagram merupakan media sosial yang paling populer, popularitas instagram kian menjulang, seiring dengan meningkatnya jumlah penggunanya, Ma'ruf (2017). Ada banyak Fitur pada smartphone yang semakin meningkat dari segi kualitas menjadi salah satu penyebabnya, dimanapun dan kapanpun kita dapat berfoto lalu mengunggah ke dalam instagram ditambah lagi instagram yang rutin melakukan pembaharuan dan ada berbagai fitur baru instagram yang mulai bermunculan.

Instagram adalah salah satu aplikasi media sosial yang diakses oleh semua kalangan, terutama kalangan anak muda. Melalui instagram, seseorang dapat mengunggah foto atau video, mempublikasikannya, dan terpampang 
pada feed pengguna yang lain, Ma'ruf (2017). Sistem pertemanan yang ada di instagram menggunakan istilah follower (pengikut) dan following (orang yang diikuti). Terdapat fitur like dan comment sehingga orang dapat leluasa memberikan apresiasi berupa tanda suka ataukomentar pada foto yang diunggah. Instagram memungkinkan bagi penggunanya untuk mengambil foto, mengedit, menerapkan filter digital, video dan membagi foto ke situs jejaring sosial seperti Instagram story, Twitter, Foursquare, Tumblr, Flickr, Posterous, dan juga jejaring sosial milik instagram sendiri. Instagram saat ini merupakan media yang unik karena di dalam media ini tidak hanya dapat berkomunikasi dengan berbagi foto saja, namun sudah merambah ke video yang mungkin saja setiap orang dapat membagi berbagai video yang menghibur dan menginformasi berbagai macam kegiatan atau rutinitas yang mereka lakukan. Kekuatan gambar telah menghubungkan orang-orang dengan apa yang sedang terjadi di dunia. Instagram mengganggap dunia lebih terhubung dan mudah dipahami melalui foto. Banyak orang mengabadikan dunia secara real time dengan instagram, lalu berbagi gambar dengan orang lain di berbagai belahan dunia (www.tekno.kompas.com). Di dalam instagram terdapatinstagram storiesatau bisa disebut dengan istilah insta story yaitu fitur baru yang diluncurkan instagram.

Pengguna instagram dapat langsung membagikan aktifitas sehari-hari baik berupa foto, video singkat dan mode ketik secara langsung kedalam kolom story agar dapat dilihat oleh followers (orang yang selalu mengikuti unggahan foto atau video yang kita bagikan) dengan ditambahkan tulisan dan efek tertentu namun hanya dapat dilihat dalam waktu 24 jam. Karena setelah melewati 24 jam secara otomatis story akan terhapus dengan sendirinya. Fitur ini adalah fitur yang sangat mirip dengan aplikasi Snapchat. Snapchat merupakan aplikasi android dan ios dan aplikasi yang berkaitan dengan komunikasi instan, melalui foto dan video, yang dikirim atau diterima di ponsel anda. Pemilik aplikasi ini adalah Evan Spiegel. Dengan aplikasi ini pengguna dapat mengambil foto, merekam video, menambahkan teks, dan mengirimkannya ke daftar penerima yang ditentukan pengguna.Stories pada Snapchat diluncurkan pada Oktober 2013, Intagram pada Agustus 2016. Keduanya terpaut 2 tahun 10 bulan. Pertumbuhan Snapchat menyusut hingga 82 persen setelah instagram stories di luncurkan (www.abonu.com). Adapun perbedaan instagram story dengan snapchat adalah tampilan awal dari masing-masing aplikasi,story yang di bagikan melalui instagram storyasalkan akun tersebut tidak di privatebisa dilihat oleh siapapun meski tidak menjadi follower. Sebaliknya di snapchat kita tidak akan bisa melihat aktivitas akun seseorang jika tidak berteman (www.digitalmarketer.id). Alasan penulis lebih memilih instagram story di bandingkan snapchat karena memang penulis tidak menggunakan snapchat,pengguna instagram storysecara global juga lebih banyak dibandingkan snapchat, dan juga fitur-fitur yang ada pada instagram story lebih menarik dan lebih banyak dibanding snapchat.Banyaknya pengguna instagram story dibandingkan snapchat dapat dilihat dari gambar berikut :

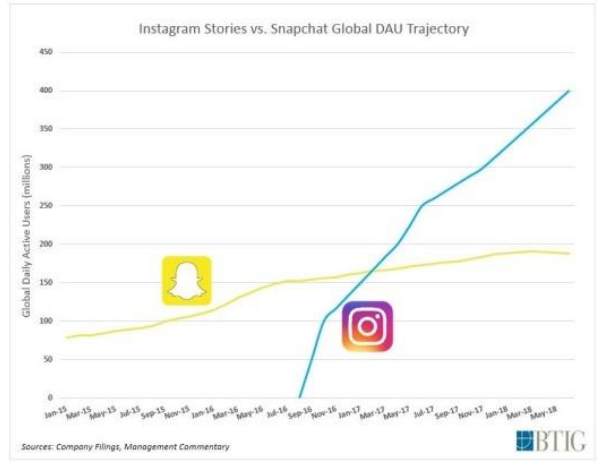

Gambar 1.1

Pengguna Intagram Story dan Snapchat 
Keterangan gambar di atas garis kuning adalah grafik pengguna media sosial snapchat dan garis biru grafik pengguna media sosial instagram story, dapat dilihat bahwa pengguna instagram story mencapai 400 juta orang per haril, lebih banyak dibandingkan pengguna snapchat yang hanya mencapai 188 juta orang per hari. Pengguna media sosial instagram semakin banyak karena instagram memudahkan penggunanya mengunggah foto dan video dalam akun yang dimiliki dan berbagai fitur pada instagram menjadi salah satu daya tarik. Dari tahun ke tahun pengguna instagram semakin banyak. Basis pengguna instagram berkembang jauh lebih cepat di banding jejaring sosial lainnya. Di dunia pengguna aktif bulanan alias monthly active user (MAU) Instagram tembus 1 miliar per Juni 2018. (https://tekno.kompas.com). Banyaknya pengguna instagram Hal ini dibuktikan berdasarkan gambar berikut :

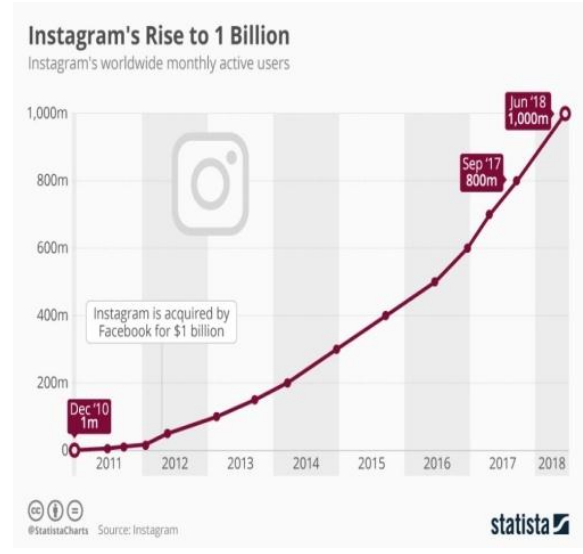

\section{Gambar 1.2 Pengguna media sosial Instagram di Dunia (sumber grafik: statista.com, 2018)}

Instagram merupakan media sosial yang progresif melakukan perubahanperubahan pada fiturnya, yang tidak membuat penggunanya jenuh. Instagram yang multifungsi tak lepas dari penggunanya, pengguna instagram banyak dari berbagai kalangan umur ada yang masih anak-anak, remaja, dewasa dan juga dari komunitas. Menurut Hendro Puspito, pengertian komunitas adalah suatu kelompok sosial atau kumpulan nyata, teratur, dan tetap dari individu-individu yang melaksanakan peran-perannya secara berkaitan guna mencapai tujuan bersama (www.maxmanroe.com).

Fenomena instagram story pada akun instagram tidak hanya terjadi dikalangan selebritis saja, melainkan juga pada masyarakat biasa seperti halnya masyarakat kota Bengkulu. Trend ini telah diikuti oleh kalangan masyarakat yang pastinya memiliki akun instagram. Pemanfaatan instagram dikalangan komunitas di kota Bengkulu tidak terlepas dari berbagai faktor yang mendorong para anggota memanfaatkan instagram tersebut. Misalnya dengan mengikuti kegiatan dan bergabung dengan komunitas-komunitas dimana dapat memberikan pembelajaran diri tentang pentingnya nilai-nilai interaksi sosial. Kekuatan suatu komunitas adalah kepentingan bersama dalam memenuhi kebutuhan kehidupan sosial yang biasanya didasarkan atas kesamaan latar belakang budaya, ideologi, sosial- ekonomi. Disamping itu secara fisik suatu komunitas biasanya diikat oleh batas lokasi atau geografis masing-masing komunitas, karenanya akan memiliki cara dan mekanisme yang berbeda dalam menanggapi dan menyikapi keterbatasan yang dihadapinya serta mengembangkan kemampuan kelompoknya.

Semakin meningkatnya peminat instagram dikalangan komunitas menimbulkan keinginan untuk mengetahui hal apa saja yang mendorong anggota dalam suatu komunitas memanfaatkan instagram tersebut dalam kehidupan sehari-hari. Salah satu komunitas yang ada di kota Bengkulu ini adalah komunitas sanggar seni Arastra, sanggar Arastra adalah sanggar seni tari dan musik dol yang beranggotakan 39 orang. Yang terdiri dari 13 penari perempuan dan 26 pemusik laki-laki. Sanggar Arastra beralamatkan di Jalan Pembangunan, Padang Harapan, Jembatan Kecil Singgaran Pati Taman Budaya kota 
Bengkulu. Berdasarkan hasil observasi awal penulis Semua anggota Arastra sudah menggunakan handphone android seperti Samsung, Oppo, iPhone dll yang mana memudahkan mereka untuk menggunakan media sosial seperti instagram.

Pada instagram, komunitas Sanggar Arastra aktif menggunakan media sosial instagram story, terlihat dari seringnya mengunggah foto, video dan teks dalam instagram story bisa mencapai 5 hingga 15 kali unggahan dalam sehari. Hal itu juga yang membuat penulis memilih Sanggar Arastauntuk diteliti. Anggota Sanggar Arastra lebih memilih sering mengunggah di instagram story dari pada instagram kronologi karena mereka menganggap insta story lebih asik dan fitur-fitur nya lebih banyak dibandingkan insta kronologi. Setiap anggota komunitas yang mengunggah instagram story akan membutuhkan frekuensi dan durasi waktu yang cukup bervariasi dan perilaku yang akan membentuk sebuah motif dalam penggunaan instagram. Seringnya anggota Sanggar Arastra dalam mengunggah foto, video dan teks ke dalam Instagram Story dapat dibuktikan berdasarkan gambar berikut:

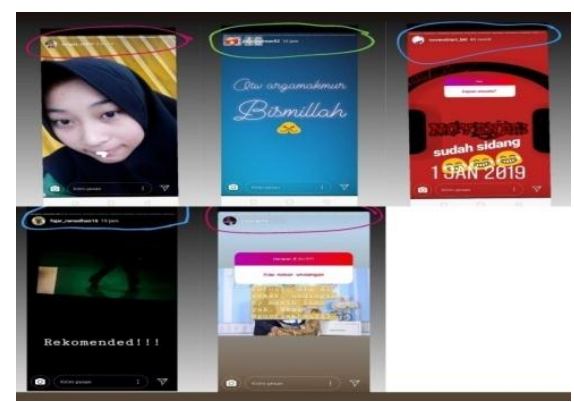

\section{Gambar 1.3 Instagram Story Anggota Sanggar Arastra, Hasil Observasi 2018}

Motif-motif tertentu yang mendorong anggota menggunakan instagram akan membentuk motif tersendiri dalam penggunaan instagram tersebut. Motif adalah suatu dorongan yang timbul dari dalam diri seseorang yang menyebabkan orang tersebut mau bertindak melakukan sesuatu, Uno (2008). Jadi, alasan penulis meneliti motif pada sanggar Arastra adalah karena fenomena semakin banyak dan aktifnya komunitas Arastra yang mengunggah foto, video, dan teks diinstagram storysehingga membuat penulis merasa tertarik untuk mengetahui motif/alasan mereka dalam mengunggah foto, video dan teks diinstagram story tersebut.

Penggunaan instagram dari kalangan komunitas yang ada di kota Bengkulu, penting untuk diteliti mengingat para anggota suatu komunitas menempati posisi strategis di tengah-tengah kehidupan masyarakat. Para anggota Arastra yang sebagian besar waktunya digunakan untuk bermain-main dengan media sosial instagram tentunya akan mengurangi waktunya untuk hal lain yang juga cukup penting, jika instagram digunakan dengan motif yang baik dan positif serta pola yang baik tentunya akan memberi manfaat yang positif.

\section{METODE PENELITIAN}

Penelitian yang digunakan dalam penulisan skripsi ini adalah jenis penelitian deskriptif kualitatif karena jenis penelitian ini berupaya menggambarkan fenomena atau kejadian sesuai dengan apa yang terjadi di lapangan, di mana data yang dihasilkan berupa kata-kata tertulis dari orang-orang dan perilaku yang diamati, Moleong (2010).

Jenis penelitian ini menggunakan pendekatan kualitatif yakni prosedur penelitian yang menghasilkan data-data deskriptif berupa kata-kata tertulis atau lisan dari orang-orang dan perilaku yang diamati. Selain itu, data-data yang dikumpulkan dilapangan adalah data yang berbentuk kata dan perilaku, kalimat, skema, gambar dengan latar belakang alamiah, dan manusia sebagai instrumennya.

Pada penelitian kualitatif hal yang menjadi bahan pertimbangan utama dalam pengumpulan data adalah pemilihan informan. Informan penelitian merupakan 
subjek yang memahami informasi sebagai pelaku ataupun orang lain yang mengetahui tentang penelitian yang dilakukan. Informan (narasumber) penelitian orang yang memiliki informasi (data) banyak mengenai objek yang sedang diteliti, untuk dimintai informasi mengenai objek penelitian tersebut. Informan dalam penelitian ini berjumlah 5 orang, terdiri dari 3 orang laki-laki dan 2 orang perempuan.

\section{HASIL PENELITIAN DAN PEMBAHASAN}

Untuk mengetahui motif anggota sanggar Arastra dalam mengunggah instagram story. Penulis menggunakan teori motif. Motif adalah kehendak dalam diri khalayak, memberikan harapanharapan untuk mencari dan memenuhi kebutuhannya. Menurut Papacharissi dan Rubin dalam Alfafa (2017) ada beberapa motif, yaitu motif entertainment, motif passing time, motif convenience, motif utility dan motif seeking information.

Kelima motif ini mewakili berbagai motif yang sering dilakukan dalam menggunakan instagram, seperti mengisi waktu kosong, atau merasakan kebosanan dan penat hingga butuh hiburan, mencari informasi-informasi yang dibutuhkan ataupun kejadian-kejadian yang sedang terjadi. Motif yang akan diteliti dalam penggunaan responden pada media sosial instagram, akan diukur berdasarkan motif menurut Papacharissi dan Rubin, sehingga bisa dilihat motif mana yang dominan melatarbelakangi pengguna media sosial instagram story. Setiap motif pengguna instagram akan membentuk pola tertentu dalam penggunaan instagram tersebut. Penggunaan instagram story dengan motif yang kurang baik tentunya akan menjadikan penggunaan instagram tersebut sebagai sebuah aktifitas yang membuang-buang waktu secara sia-sia. Penelitian ini ingin mengungkapkan motif dari anggota sanggar Arastra pengguna media sosial instagram di kota Bengkulu yang gemar dalam mengunggah instagram story.

\section{Motif Entertainment}

Dorongan setiap manusia dalam mencari hal yang berbeda dari rutinitas, tidak berpikir secara berat, mencari hal-hal yang ringan yang membuat relaksasi pada diri individu, mengembalikan stimulus yang positif, meluapkan emosi dan melupakan kejenuhan dalam rutinitas.

Media sosial instagram adalah media yang menjadi hiburan bagi anggota sanggar Arastra. Motif entertainment atau motif hiburan adalah salah satu alasan yang mendasari para mereka dalam seringnya mengunggah foto, video dan teks ke dalam instagram story. Salah satu motif mereka dalam seringnya mengunggah instagram story adalah mencari hiburan atau mengatakannya menggunakan media sosail instagram adalah merupakan suatu bentuk kebutuhan untuk menjadi penghibur akan diri sendiri karena instagram story dinilai sangat menghibur, mereka dapat melihat bermacam-macam peristiwa lucu, sedih, konten, tentang musik doll, video lucu serta tutorial hijab dan make up yang unik bagi wanita.

Penggunaan media menurut pendapat Snow (dalam Rahim :2018) adalah untuk menciptakan dan memeliharakan perilaku rutin dan juga untuk membantu memelihara ritme dan suasana hati. Misalnya mengakses instagram story untuk mencurahkan suasana hati baik saat merasa senang, sedih, ataupun marah di status sehingga perasaan emosi itu bisa disalurkan. Hal ini senada dengan hasil temuan penulis, yaitu melalui instagram story mereka membagikan ceritayang menunjukkan perasaan senang, sedih maupun marah. Mereka juga membagikan aktivitas sehari-hari agar dilihat oleh pengguna lain dan agar mendapatkan respon dari teman-teman yang ada di instagram. Saat menjalani aktivitasnya di dunia nyata atau media sosial instagram, 
mereka bertujuan untuk menampilkan sosok dirinya sebaik mungkin. mereka menginginkan keberadaan dirinya di media sosial instagram dapat diakui oleh pengguna lainnya. Mereka yang merupakan anggota sanggar Arastra yang ingin dirinya terlihat menjadi pusat perhatian.

Semakin aktifnya seseorang di media sosial maka mereka semakin dianggap keren dan gaul. Media sosial menghapus batasan-batasan dalam bersosialisasi, dalam media sosial yang kita tahu bahwa tidak ada batasan ruang dan waktu, mereka dapat mengunggah apapun, kapanpun dan dimanapun mereka berada. Bagaimana anggota sanggar Arastra menggunakan hiburan saat ini sesuai dengan kebutuhannya, menjadi hal yang wajar bila yang dikatakan bahwa mereka disibukkan dan di penuhi dengan rutinitas yang cukup padat yang membuat mereka beralih dari kehidupan sosial yang nyata dan menggunakan instagram sebagai sarana hiburan.Hal tersebut sesuai pada konteks kebutuhan mereka akan hiburan. Bagi anggota sanggar Arastra, media sosial instagram dapat mengubah suasana hati yang dikehendaki ini artinya bahwa mereka menggunakan instagram story sesuai dengan apa yang ingin mereka lakukan dan sampaikan sesuai dengan pemikiran mereka. Dengan mereka melihat meme dan video-video lucu yang di unggah oleh akun hiburan di instagram.

Dalam motif ini penulis melihat salah satu alasan mereka sering mengunggah instagram story adalah sebagai pemenuhan kebutuhan akan hiburan untuk diri mereka.Unggahan pada instastory, fitur dan konten penggunaan dari media sosial instagramstory membuat para anggota sanggar Arastra menjadi senang dan dapat mengalihkan pikiran dari hal-hal yang menggangu dan membuatnya merasa menjadi lebih senang.

\section{Motif Passing Time}

Dorongan melakukan sesuatu ketika waktu kosong atau meluangkan waktu dengan dirinya sendiri, sering dihabiskan khalayak sambil bersantai dengan melihat konten-konten yang ada. Penggunaan media sosial instagram adalah pilihan anggota sanggar Arastra untuk mengisi waktu luang atau kosong. Motif passing time atau mengisi waktu kosong adalah alasan para anggota sanggar Arastra dalam bermain instagram dengan melihat-lihat video-video lucu, unggahan pada instagram story milik teman-teman dan melihat unggahan para selebritis.Fajar, Noven dan Jhoni untuk mengunggah di instagram story hanya membutuhkan waktu yang sebentar yaitu kurang lebih hanya 1 menit, berbeda dengan Puja dan Anggia yang butuh waktu 2 hingga 5 menit kemudian karena mereka harus memilih-milih yang paling bagus menurutnya dan terkadang sampe mengulang-ulang dalam pengambilan gambar untuk mendapatkan hasil yang bagus yang ingin di posting.

Kebanyakan dari mereka sama-sama sering mengunggah instagram storyketika mereka ada kegiatan-kegiatan yang dilakukan seperti sedang jalan-jalan, sedang pergi makan di suatu tempat dan acara formal, tidak hanya pada waktu luang, jam-jam penting pun dimanfaatkan oleh mereka untuk bermedia sosial. Sebagian besar orang memiliki sifat yang tidak dapat terpisah dari sosial media instagram oleh karena itu hampir di setiap waktunya dilewati dengan bermain instagram.karena terlalu sibuk dengan dunia maya membuat mereka sering kali mengabaikan dunia nyata di sekitarnya dan mengganggu aktivitas kerja atau belajar sehari-hari. Ketika adanya waktu kosong tidak digunakan oleh anggota sanggar Arastra untuk bekerja atau belajar karena mereka merasa dirinya juga butuh hiburan akan kesenangan untuk dirinya sendiri dari kesibukan bekerja dan belajar serta dari kegiatan komunitas yang mereka ikuti. 
Waktu kosong yang ada di gunakan oleh mereka untuk bermain instagram dengan melihat-lihat akun-akun yang mengunggah video-video lucu. Berbeda dengan salah satu dari mereka yang lebih sering mengunggah instagram story ketika waktu santai. Beberapa orang sangat aktif di instagram ketika ia memiliki waktu luang. Mereka terlihat mengunggah pada instagram story dan melihat-lihat konten yang ada di instagram. Dalam motif ini penulis melihat bahwa mereka bermain instagram, mengunggah instastory, melihat konten-konten lucu dan menarik untuk mengisi waktu kekosongan mereka. Mereka menghabiskan waktu untuk mengunggah ke dalam instagram story 1 hinggal 5 menit dalam sekali unggahan.

\section{Motif Convenience}

Dorongan pengungkapan diri, menentukan perilaku dengan nilai-nilai yang ada pada gambar suatu media dan meningkatkan tentang pemahaman akan diri sendiri. Motif Convenience pada anggota sanggar Arastra dalam penggunaan instagram story, dapat menjalin hubungan dengan orang lain, merasa nyaman karena instagram dapat di akses kapan saja dan dimana saja. mereka juga merasa dimudahkan berinteraksi dengan orang banyak dalam waktu yang bersamaa melalui instagram. Unggahan pada instagram story mereka adalah bentuk dari mereka mengekspresikan diri, sesuatu hal yang ditunjukkan oleh seseorang individu, baik dalam bentuk perkataan, penampilan, gaya rambut atau dalam bentuk berkesenian seperti menulis. Mereka merasa mempunyai kebebasan dalam konten yang ingin mereka unggah baik berupa foto, video dan teks.Instagram story juga sebagai wadah mereka mencurahkan perasaan yang dirasakan baik perasaan senang, sedih maupun marah agar emosi yang dirasakan tersalurkan.

Dari hasil pengamatan penulis bahwasanya mereka menempatkan pandangan orang lain menjadi perioritasnya sebagai tujuan mereka untuk update aktivitas mereka melalui media sosial instagram. dari postingan mereka dapat dilihat siapa saja yang memperhatikan aktivitas mereka, semakin banyak yang melihat dan merespon semakin sering informan untuk memposting aktivitasnya di instagram story. Dengan banyaknya fitur instagram story juga membuat mereka semakin seringnya posting dengan mencantumkan nama, asal, lokasi dan sedemikian rupa informan buat agar dapat direspon maupun di pahami oleh orang-orang bahwasanya informan sedang dimana, dengan siapa dan melakukan aktivitas apa, bahkan hal tersebut dapat meningkatkan eksistensi diri informan sendiri.

Keberadaan diri yang diakui oleh orang lain tak jarang membuat mereka bisa merasa bahagia. Pengakuan dari orang lain atas eksistensi diri menjadi tolak ukur kebahagian, sehingga rasanya hidup belum sempurna jika belum ada orang yang memberikan pujian atau pengakuan yang tinggi pada diri mereka. Akan tetapi tidak semua orang memuji unggahan pada instagram story mereka, pernyataan yang sama dilontarkan oleh sebagian dari mereka yang mengatakan " bahwa terkadang unggahan foto, video dan teks pada instagram story nya terdapat kometar negatif dari pengguna akun instagram lain yang berdampak buat diri saya sedih dan mulai membuat saya sedikit mengurangi untuk mengunggah instagram stoty". Dari pengamatan penulis bahwa mereka yang biasanya mengunggah di instagram story dalam sehari bisa mencapai 10 kali instastory, dalam satu bulanan ini mereka hanya mengunggah instastory 3 hingga 6 kali dalam sehari.

\section{Motif Utility}

Dorongan yang berasal dari keperluan khalayak pada sesuatu dengan harapan hal itu tidak pernah di dapatkan sebelumnya, dan dipenuhi kebutuhannya dan merasa puas. Motif utility pada anggota sanggar Arastra dalam penggunaan instagram 
story, Hasil penelitian ini menunjukan bahwa tingkat kepuasan anggota sanggar Arastra dalam menggunakan media sosial instagram termasuk dalam tingkat kepuasan yang puas dan cukup puas, dari mereka ada beberapa anggota yang merasa puas dan cukup puas setelah mengunggah foto, video atau teks ke dalam instagram story, mereka merasa puas setelah mereka mengunggah foto, video atau teks ke dalam instagram story mereka mendapatkan respon atau komentar dari teman-teman yang ada di instagram. Mereka merasa dapat mengunggah konten apapun sesuai dengan kepentingannya dan sesukanya dalam mengunggah ke instagram story. Meskipun hanya sebatas cukup puas, tetapi mereka tetap menggunakan media sosial instagram dan mereka tetap aktif dalam bermain instagram story.

Dengan instagram story mereka dapat mengunggah foto, video dan teks disetiap momen yang sangat mendukung untuk menunjukkan eksistensi penggunanya. Eksistensi sendiri dapat diartikan sebagai ada atau menunjukkan bahwa diri seseorang itu ada. Sehingga eksistensi diri dalam media sosial itu merupakan pembuktian keberadaan seseorang melalui penggunaan media online, khusunya instagram. Namun dengan adanya teknologi dan media online yang berkembang seperti instagram membuat pola komunikasi ikut berubah, cara memahami eksistensi diri pun ikut berubah meyebabkan komplesitas kehidupan seolah-olah telah menjadi bagian dari kehidupan bermasyarakat. Dimana para pengguna Instagram khususnya kalangan anggota sanggar arastra beranggapan dengan membagikan gambar, foto maupun video tentang kehidupan kesehariannya merupakan satu-satunya cara dalam menunjukkan eksitensi diri mereka dan kepuasan yang diperoleh mereka. Dalam motif ini penulis melihat motif dibalik seringnya mereka dalam mengunggah foto, video dan teks di instagram story untuk mendapatkan kepuasan diri yang membuat mereka puas dan cukup puas.

\section{Motif Seeking Information}

Kelahiran manusia secara individu, membuat seseorang manusia memiliki karakteristik berbeda-beda sehingga manusia memiliki dorongan akan interaksi sosial demi mendapatkan sebuah pengetahuan baru dengan cara mendapatkan suatu informasi, dan memilah informasi ini dari rasa akan mendorong manusia lebih percaya diri untuk bergaul dengan lingkungan sosialnya.

Motif seeking information pada anggota sanggar arastra dalam penggunaan instagram story, mereka dapat mengetahui berita dan informasi yang ada di indonesia maupun luar negeri. Mereka juga dapat mengetahui informasi mengenai kegiatan dari teman-teman mereka, aktivitas yang dilakukan orang lain. Di Jaman sekarang informasi tidak hanya diberikan dalam bentuk artikel atau tulisan. Dengan adanya instagram mereka dapat membagikan informasi melalui foto, baik itu peristiwa, lokasi dan informasi lainnya. Setelah mengunggah foto, video atau teks kedalam instagram story membuat mereka lebih percaya diri untuk bergaul atau berteman dilingkungan sosialnya tetapi tidak bagi beberapa dari mereka, ia merasa dengan mengunggah pada instagram story tidak berpengaruh terhadap kepercayaan dirinya saat berada atau sedang berkumpul di lingkungan sosialnya. Dengan bermain instagram membuat mereka lebih mendapatkan banyak teman di instagram. Cara mereka berinteraksi dengan temanteman yang ada di instagram dengan cara saling mengomentari unggahan yang ada pada instagram story,dan dengan cara mengunggah instagram story dengan menggunakan fitur tanya jawab sudah dapat membentuk komunikasi dengan teman-teman yang ada di instagram.

Dari paparan diatas, dapat disimpulkan bahwa motif mereka dalam 
mengunggah foto, video dan teks di instagram story adalah motif convenience, motif utility, motif passing time, motif entertainment, dan motif seeking informationseperti yang ditemukan pada teori Papacharissi dan Rubin (2017), Penulis menyimpulkan motif convenience sebagai motif yang paling dominan karenaapa yang mereka unggah adalah bentuk mereka mengekspresikan diri, tempat mencurahkan perasaan yang dirasakan dalam bentuk foto, video dan teks. Baik perasaan senang, sedih maupun marah agar emosi yang dirasakan tersalurkan dan pada unggahan mereka membentuk citra yang baik agar mendapatkan pengakuan yang mereka inginkan. Pada motif utility, tidak semua dari mereka yang merasakan kepuasan setelah apa yang mereka unggah pada instagram story, ada yang merasa puas dan cukup puas. Pada motif entertainment hanya sebatas media sosial yang memberikan sedikit hiburan dan rasa senang yang mereka rasakan. Pada motif passing time, tidak semua dari mereka menggunakan waktu luang yang ada untuk bermain dan mengunggah foto, video dan teks di instagrm story, karena ada juga yang menggunakan waktu luangnya untuk beristirahat bagi yang sudah bekerja. Pada motif seeking information, mereka mengunggah instagram story tidak selalu memberikan sebuah informasi kepada pengguna lainnya. Contohnya ketika mereka hanya mengunggah foto selfie ke instagram story.

Penulis juga menyimpulkan bahwa motif mereka dalam menggungah foto, video dan teks bukan hanya dari kelima motif teori Papacharissi dan Rubin(2017). Motif lainnya adalah sebagai ajang pamer apapun yang mereka lakukan. Misalnya pamer saat bisa makan di tempat-tempat mewah, saat jalan-jalan atau pamer pacar baru. Pamer pencapaian yang pernah diraih.Kedua adalah motif ikut-ikutan trend masa kini, seperti yang trend pada saat ini adalah menyebut-nyebut kebaikan orang di media sosial. Mereka akan memposting pemberian dari orang lain dengan mention akun orang tersebut. Dalam penggunaan instagram, mereka dikategorikan berlebihan ketika menggunakan instagram, hal ini bisa dilihat dari seringnya mengunggah foto, video dan teks di instagram story. yang membuat mereka menjadi lebih boros, konsumeris dan individualis.

Dalam penggunaan media sosial instagrampasti terdapat kelebihan dan kekurangannya. Adapun kelebihan dan kekurangan dari penggunaan Instagram adalah sebagai berikut:

Kelebihan penggunaan instagram adalah:

1. Menjadi wadah untuk mengekspresikan diri

2. Dapat dikenal oleh banyak orang

3. Sarana bersosialisasi sehingga bisa memiliki banyak teman

4. Dapat mengetahui banyak informasi, seperti tempat makan yang enak, tempat wisata yang bagus, aktivitas teman-teman, berita yang ada di indonesia maupun luar negeri

5. Promosi bisnis online yang sangat mudah

Sedangkan kekurangan penggunaan instagram adalah :

1. Instagram dapat membuat para remaja kecanduan sehingga malas belajar karena terlalu asik bermain instagram

2. Instagram membuat orang menjadi individualis

3. Membuat lebih boros penggunaan kuota internet

4. Dapat membuat para remaja menjadi diri orang lain, bukan menjadi dirinya sendiri

5. Rawan bullyan 


\section{PENUTUP}

\section{Kesimpulan}

Berdasarkan hasil penelitian dan pembahasan, maka motif anggota sanggar Arastra dalam mengunggah foto, video dan teks pada media sosial instagram story adalah bervariasi alasannya., tapi yang paling dominan adalah motif convenience. Sedangkan motif yang lainnya hanya mengikuti. Penjelasan singkatnya sebagai berikut:

1. Motif convenience, apa yang mereka unggah bentuk dari mereka mengekspresikan diri, tempat mencurahkan perasaan yang dirasakan dalam bentuk foto, video dan teks. Baik perasaan senang, sedih maupun marah agar emosi yang dirasakan tersalurkan.

2. Motif entertainment atau hiburan, instagarm adalah media hiburan yang memberikan kesenangaan dari kejenuhan yang mereka rasakan, mereka dapat melihat konten-konten yang mereka sukai yang dapat memberikan hiburan.

3. Motif passing time, mereka menggunakan waktu luang yang ada untuk bermain dan mengunggah foto, video atau teks di instagrm story.

4. Motif seeking information, mereka mengunggah instagram story untuk memberikan informasi dan melihatlihat akun instagram lainnya agar mendapatkan sebuah pengetahuan baru dengan cara mendapatkan informasi melalui instagram tersebut.

5. Motif utility, mereka merasakan kepuasan setelah apa yang mereka unggah pada instagram story, di lihat oleh banyak pengguna lainnya dan mendapatkan respon yang postif atau sebuah pujian.

6. Hasil temuan terdapat motif pamer, pamer saat bisa makan di tempattempat mewah, saat jalan-jalan atau pamer pacar baru. Pamer pencapaian yang pernah diraih.
7. Motif ikut-ikutan trend masa kini, seperti trend pada saat ini adalah menyebut-nyebut kebaikan orang di media sosial. Mereka akan memposting pemberian dari orang lain dengan mention akun orang tersebut.

\section{Saran}

Berdasarkan penelitian yang telah dilakukan, penulis memiliki beberapa saran yang perlu diperhatikan, antara lain sebagai berikut :

1. Sebagai pengguna instagram sebaiknya anggota sanggar Arastra tidak berlebihan dalam bermain instagram, karena terlalu sibuk dengan dunia maya kita sering kali mengabaikan dunia nyata di sekitarnya dan mengganggu aktivitas kerja atau belajar sehari-hari.

2. Anggota sanggar Arastra hendaknya memanfaatkan instagram untuk halhal yang lebih berguna seperti jualan online yang dapat menghasilkan pendapatan dan memberikan informasi-informasi yang bermanfaat buat pengguna lainnya.

3. Hasil penelitian ini tentunya masih jauh dari kata sempurna, sehingga penulis menyarankan agar penelitian ini dapat dikembangkan lagi oleh peneliti lainnya dan dapat menggali data lebih dalam mengenai hal tersebut sehingga menemukan motifmotif baru.

\section{DAFTAR PUSTAKA}

Ahmadi, Abu. 2009. Psikologi Sosial. Jakarta, Rineka Cipta

Ardianto,Elvirano.Dkk.2014. Komunikasi Massa Suatu Pengantar Edisi Revisi Bandung

Arikunto,Suharsimi.2006.Prosedur Penelitian (Suatu Pendekatan Praktek) Jakarta,Rineka Cipta.

Gerungan.2004.Psikologi Sosial.Bandung, Aditama 
Moleong, Lexy J. 2011. Metode Penelitian Kualitatif. Bandung, Remaja Rosadakarya Pelajar

Pasolong, Harbani. 2013. Metode Penelitian Administrasi

Publik.Bandung,

Alfabeta

Rakhmat, Jalaluddin.2012. Psikologi Komunikasi. Bandung, Remaja Rosda Karya

Siregar, Sofian,2014. Metode Penelitian Kuantitatif. Jakarta,Kencana Prenamedia Group

Uno, Hamzah B. 2008. Teori Motivasi dan Pengukurannya. Jakarta, Bumi Aksara

\section{Sumber Skripsi:}

Alfafa i, Silma Rahmah. 2017. Motif Pengguna New Media (studi pengaruh pengguna instagram di kalangan mahasiswa fakultas dakwah dan komunikasi sunan kalijaga Yogyakarta). Fakultas Dakwah dan Komunikasi, Universitas Sunan Kalijaga Yogyakarta

Bestari. 2014. Fenomena Mengunggah Foto Makanan Pada Pengguna Media Sosial. Fakultas ilmu sosial dan ilmu politik Universitas Indonesia.

Novian. 2015. Analisis Foto Selfie Sebagai Media Mengekspresikan Diri (Studi Pada Account Instagram Kurt Coleman). Fakultas Ilmu Sosial dan Ilmu Politik, Universitas Lampung

Rahim, Muhammad. 2018. eJournal llmu Komunikasi, 6 (3): 263-275 ISSN
2502-5961 (Cetak), 2502-597x (Onilne), ejournal.ilkom.fisipunmul.org (C) Copyright 2018

$\begin{array}{lrr}\text { Susanti.2014. } & \text { Fenomena } & \text { Perilaku } \\ \text { Pengguna Tongsis } & \text { (Tongkat } \\ \text { Narsis) Dikalangan Siswa } & \text { SMK } \\ \text { Yapri } & \text { Aktripa } & \text { (Studi } \\ \text { Fenemomenologi Tongkat } & \text { Narsis) } \\ \text { Dikalangan Siswa SMK } & \text { Yapri- } \\ \text { Aktripa Bandung. Fakultas Ilmu } \\ \text { Sosial Dan Ilmu Politik Universitas } \\ \text { Pesundan Bandung. } \\ \text { Utaminingtyas, Siwi. 2012. Pengaruh } \\ \text { Penggunaan Media } \text { Video } \\ \text { Terhadap Kemampuan Menyimak } \\ \text { Dongeng Pada Mata Pelajaran } \\ \text { Bahasa Indonesia Siswa Kelas V } \\ \text { Sd Negeri Panjatan, Kulon Progo, } \\ \text { Yogyakarta: Eprints Uny }\end{array}$

Veronica, Eny. 2012. Upaya Mempertahankan Eksistensi Tari Kridha Jati di Sanggar Hayu Budaya Kelurahan Pengkol Jepara. Jurnal Jurusan Sendratasik FBS. Semarang: UNNES PRESS

\section{Sumber Internet :}

http://www.CnnIndonesia.com https://www.Tekno.Kompas.com https://www.cnbc.com http://Statista.com/image www.abonu.com https://plus.kapanlagi.com http://ilmuti.org/wpcontent/uploads/2014/0 4/Esty_Maulina_Macam_macam_Media_ Sosial.pdf 